LWSA

PAPER - OPEN ACCESS

\title{
Mandarin Vocabularies Translation Strategies Related to Export Sales of Paper-Based Packing
}

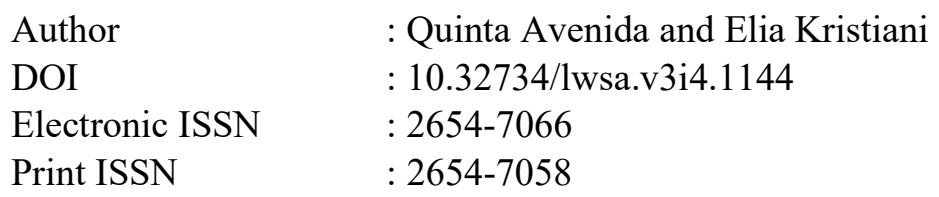

Volume 3 Issue 4 - 2020 TALENTA Conference Series: Local Wisdom, Social, and Arts (LWSA)

\section{(c) $\underset{\mathrm{EY}}{\ominus} \mathrm{No}$}

This work is licensed under a Creative Commons Attribution-NoDerivatives 4.0 International License.

Published under licence by TALENTA Publisher, Universitas Sumatera Utara

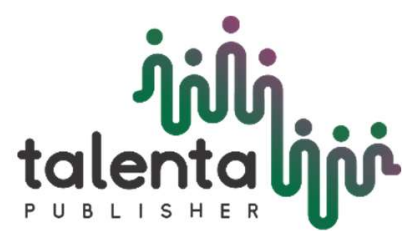




\title{
jiditi

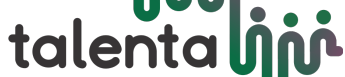 \\ LWSA Conference Series 03 (2020)

\section{Mandarin Vocabularies Translation Strategies Related to Export Sales of Paper-Based Packing}

\author{
Quinta Avenida, Elia Kristiani \\ Universitas Sebelas Maret, Jalan Ir Sutami No. 36 A, Surakarta, Indonesia \\ quintavenida@staff.uns.ac.id, eliakristiani@student.uns.ac.id
}

\begin{abstract}
Translation strategy, according to Suryawinata et al. (2003, p. 67), is a translation tactic to translate words, phrases, and full sentences if the sentences cannot be divided into a smaller translated-unit. Therefore, the translation strategy has a great impact on the translation process from the source language to the target language so that accurate and understandable translation results can be produced. PT. Mulia Cipta Teknologi, located in Boyolali, is a company working in export sales of paper-based packaging. It produces paper roll whose weight is up to one ton. The item is used as a raw material to produce cardboard boxes exported to some factories in China. The sales process is closely related to the use of Mandarin. This research aims to give a Chinese to Bahasa Indonesia translation strategy related to terms commonly used in paper-roll export documents. Data collection techniques being performed were participant observations, interviews, and documentation.
\end{abstract}

Keywords: translation strategy; export terms in Chinese; paper-roll

\section{Introduction}

Rapid technological development has caused a faster flow of economic growth. Corrugated boxes are one of the packaging examples usually preferred by many people. According to the 92nd edition of Print Media Magazine, the corrugated boxes are predicted to be a trend in packaging industries in the year 2020. The magazine also added that the corrugated boxes will dominate the packaging sector as they have firm and stable structure. As part of recyclable material, they also have replaced the use of plastics. The corrugated boxes themselves are made of a corrugated paper roll. As a result, the number of local and foreign companies which are now working together in the field of goods packaging has increased.

In Indonesia, many industrial sectors have tried to adjust themselves to international markets. PT. Mulia Cipta Teknologi, established in Boyolali, has tried to develop their corrugated paper roll production to China. In paper roll export sales, a found obstacle is the absence of an active or passive translator in the export field, especially paper roll one.

The discussion will mostly talk about the translation strategy related to Chinese terms which do not have equivalent terms in Bahasa Indonesia. The terms were found in documents of paper roll packaging export sales. By learning the Chinese terms on the documents, the paper roll quality is expected to improve and the export can be accelerated.Based on observations, students studying Japanese in the city of Medan experience difficulties when changing Japanese verbs to the form of a causative verb. So that there is a lot of difficulty in using it. This error occurs because learners often change the Japanese causative verbs to the form of Kanoo Dooshi (can-form expressions) and Ukemi (passive sentences), because the changes in the form of these verbs are almost the same. Until in the end it became an obstacle that hindered the understanding of Japanese language learners in mastering material about shieki. Therefore, this paper will discuss the mistakes of students in mastering Japanese (causative verb) shieki dooshi, and it can be used as a reference in the development of Japanese language teaching in Medan..

\section{Research Theories and Methods}

This qualitative research has produced descriptive data such as interviews, literature reviews, observations, field data, and other official data in translating Chinese terms of paper roll export sales in PT. Mulia Cipta Teknologi, Boyolali. This paper is the part of a final project completion conducted by a college student, Elia Kristiani in 2020, entitled: "Chinese Vocabularies Translation Strategy in Paper Roll Export Sales in PT. Mulia Cipta Teknologi, Boyolali” under the author's supervision. The focus of this research is on analyzing Chinese terms which do not have the equivalent terms in Bahasa Indonesia found in the documents of paper roll export sales. This difference distinguishes this work from the final task. Moreover, the observations took place in PT. Mulia Cipta Teknologi. Meanwhile, a research objective includes terms found in the documents of paper roll export sales. 
Data collection techniques were acquired using participant observations, interviews, and documentation. The interviews were held orally and in-person with export staff to gain accurate data regarding the most commonly-used terms in the documents of paper roll export sales. Based on the analysis of the documents, some terms were found such as 最终用户、终端用户、高强瓦 楞纸、一方、交付条件、环压强度。

This qualitative-descriptive research is focusing on Chinese to Bahasa Indonesia translation of terms used in the paper-roll export sales documents. The study consists of three stages, which are data collection, presentation, and conclusion. The data collection was applied by document analysis, terms analysis, and terms classification. Then, analyzing and presenting tables were steps performed in the presentation stage. The last stage is about a conclusion to sum each process by testing the appropriateness and suitability of existing data.

\section{Findings and Discussion}

\subsection{Translation}

Translation refers to a meaning interpretation from the source language which produces texts with equal meanings and exact messages in the target language, as argued by Machali (2009, p. 26). He also proposed that translation is an attempt to change texts whose meanings are as intended by the author from the source language into the target one. Weiyu et al. (2020, p. 96) further explained that translation should pay more attention to translation effects on targeted readers so that the message purpose of the source language culture can be well-delivered and understood by the readers. Therefore, the translation strategy is considered necessary in the translation process.

\subsection{Export}

Export is defined as an effort to sell our commodities to other countries, expecting payment in foreign currency, using a foreign language for communication (Amir M.S, 2004, p.1).

Tandjung (2010, p. 269) stated that export is the release of goods from the Indonesian customs areas to be sent abroad following applicable provision, especially regarding customs regulations. He also added that the process is done by an exporter who has got permission from the Directorate General of Foreign Trade, the Ministry of Trade. Export can be concluded as an activity of selling goods abroad using foreign currency for payment and foreign language. This is supported by a statement written in an article entitled: "How does Economic Policy Uncertainty of the Destination Country Affect the Quality of Products Exported by Chinese Companies?". The statement said that export is not merely about selling goods overseas, but also trying to improve export production quality both domestically and internationally.

\subsection{Translation Strategy}

During the translation process, many obstacles are usually found. To overcome the translation problems, some translation strategies are required. According to Loescher (1991), as cited by Plonska (2014), a translation strategy is a procedure consciously carried out by the translator in overcoming problems when translating texts.

Throughout the translation, the translator sometimes finds it difficult to search for equivalent sentences, terms, or words from the source language to the target language. This encourages the translator to describe and provide information that helps them to translate those terms. In translating paper-roll export documents, six terms were translated using a descriptive translation strategy. Those terms are as followed:

\begin{tabular}{|c|c|c|}
\hline HANZI (汉字) & PINYIN (拼音) & MEANING (意思) \\
\hline 最终用户 & zuìzhōng yònghù & $\begin{array}{l}\text { The last consumer who receives the produced } \\
\text { goods. }\end{array}$ \\
\hline 终端用户 & zhōngduānyònghù & Bank account owned by the last customer \\
\hline 高强瓦楞纸 & gāoqiáng wăléngzhĭ & $\begin{array}{l}\text { Bursting strength of the corrugated cardboard } \\
\text { on paper-roll type }\end{array}$ \\
\hline 一方 & yīfāng & $\begin{array}{l}\text { One of the companies of two collaborating } \\
\text { corporations. }\end{array}$ \\
\hline
\end{tabular}




\begin{tabular}{lll}
\hline \multirow{2}{*}{ jiāofù tiáojiàn } & $\begin{array}{l}\text { International Commercial Terms, or known as } \\
\text { Incoterms, are a collection of terms created to } \\
\text { match understanding between sellers and } \\
\text { buyers. }\end{array}$ \\
The size that shows the ring crush will \\
环压强度 & $\begin{array}{l}\text { Tetermine the paper resistance. If the ring } \\
\text { crush number is low, the cardboard will easily } \\
\text { crumple and get soft. }\end{array}$ \\
\hline
\end{tabular}

The terms used in the business documents of paper roll sales were translated using the descriptive translation strategy to deliver the meanings accurately. The phrase of 高强瓦楞纸 does not have an equal meaning in Bahasa Indonesia. If we translate that phrase using direct translation, it will mean 'superior corrugated paper'. However, the meaning is different. The phrase refers to the bursting strength of corrugated cardboard on the paper roll type. Then, the next phrase which does not have an equivalent term is环压强度。环 itself means 'ring' or 'circle', 压 means 'pressure', 强 means 'strong', and 度 means 'degree' or 'level'. In general, 环压强度 refers to the size showing the ring crush number that determines the paper resistance. As a result, if the paper has a low ring crush number, the cardboard will easily crumple and get soft, and vice versa. By doing this translation strategy, readers will understand the meanings more easily.

\section{Conclusion}

The translation is correlated with the process of interpreting meanings from the source language to the target language. The analysis was performed by classifying the type of phrases or terms used in the documents of paper roll export. As a result, six terms that do not have equal meaning in Bahasa Indonesia were found. From the findings based on the translation process of paper roll export sales documents, it can be concluded that some terms were found to be more suitable if they were translated descriptively. The reason behind this technique is because no equivalent terms, texts, or words, from the source language can be found in the target language. If the translator masters the terms used in paper roll export well, it will simplify the translation process and paper roll export sales.

\section{References}

[1] Amin, M. 2019. Karya Ilmiah. Prosedur Penanganan Dokumen Barang Ekspor Oleh PT. Pana Lintas Sindo Pratama Batam.

[2] Arifin, Zainal dkk. 2016. Jurnal. Strategi Penerjemahan Istilah-istilah Akuntansi Managemen Dalam Buku Teks Management Accounting.

[3] [3] Nababan, Rudolf. 1997. Aspek Teori Penerjemahan dan Pengalihbahasaan. Surakarta: UNS Press.

[4] [4] Suryawinata, Zurichridin dan Sugeng Hariyanto. 2016. Translation Bahasan Teori \& Penuntun Praktis Menerjemahkan (Edisi Revisi). Malang: Media Nusa Creative.

[5] [5]阿娜尔古丽.马哈提, 乌拉别克·加米什. 毕业翻译论文中汉译哈偏误研究. 新疆农业大学, 2019年（35）：76页.

[6] [6]陈剑芬, 李艳. 初级对外汉语教材生词英译策略探析一一以汉语教程》1-3册课文生词英译为例. 西安外国语大学, 2014年（4）：82页.

[7] [7]陈君铭. 汉语文化负载词翻译策略意义分析. 湖北科技学院, 2015年（5）：62页.

[8] [8]㙜莹莹. 英汉语言差异对英语笔译的影响及翻译策略探讨. 厦门大学, 2020年 : 174-175页.

[9] [9]洪红霞. 浅谈口头翻译. 内蒙古二连浩特, 2015年 : 246页.

[10] [10]黄佩妮. 印度尼西亚对中国橡胶出口贸易研究. 安徽大学, 2019年.

[11] [11]江月亭. 进口中间品与出口产品质量 : 文献综述. 山东理工大学, 2016年.

[12] [12]李海玲. 谈翻译是翻译文化. 新疆则经大学, 2015年：96页.

[13] [13]牛 艳. 从语用顺应论的角度看翻译策略与方法. 中北大学，2019年（22）：41页.

[14] [14]全家庆. 浅析口译与笔译的区别. 安徽文学, 2014年：131页.

[15] [15]苁 琰. 中英文化背景下的翻译策略. 江西电力职业技术学院，2015年（4）：71页. 